УДК 331.1: 378.091 .39

\title{
BUSINESS GAME AS WAY TO INCREASE EFFICIENCY OF EDUCATIONAL PROCESS IN STUDY TOPICS PROVIDING OF FIRST AID TO VICTIMS IN ACCIDENTS
}

\author{
S. M. Holopura, P. O. Chmara \\ National University of Life and Environmental Sciences of Ukraine, Ukraine. \\ Speciality of article: 133 - industry engineering. \\ Corresponding authors: svgolopura@ukr.net.
}

Article history: Received-August 2020, Accepted-October 2020.

Bibl. 20, fig. 1, tabl. 1.

Abstract. The article is devoted to the theoretical and practical use of the business game method for the professional activities of future professionals who need the necessary real practical skills, apply practical skills, using and practicing, as well as complying with the law, which requires the use of inappropriate today and organizational measures. Appointed that the problems of using the game in socio-pedagogical work are widely represented in terms of pedagogy in general research. At the same time, we consider the shortage of domestic people dedicated to the manufacturers of theoretical foundations and improved activities, using the business game as an active occupational safety training method for future professionals. Identified specialized play activities that added a touch of detail, pre-working, as a methodology that changed learning among students.

The purpose of the research is to develop, scientifically substantiate and experimentally test the methodology of the business game "Providing of first aid to victims in accidents at production", aimed at working out a sequence of actions to provide first aid in order of urgency and ability to maintain basic life functions. before the arrival of the emergency. The result of such games can be both the direct development of personality qualities and the demonstration of practical training of future professionals. Playing certain situations, involving game participants in the situation of choice is a real way to selfconfidence, the ability to properly navigate in an extreme situation and use the tools at hand to help victims.

This article analyzes the degree of assimilation of educational material by students after conducting practical classes in the form of a business game in comparison with students of control groups, in which this topic was presented in a lecture. The form of student certification consisted of answers to test tasks and descriptive questions of the training module. We compared the average scores on the 100-point system with the results of the assessments in the control groups, taking into account the overall score of students for the academic year.

Key words: business game, occupational safety and health, providing first aid to victims, extreme situation, degree of mastering of educational material.

\section{Introduction}

Global trends of humanization, integration and globalization of society determine new priorities for the development of education. The tasks facing modern education today determine a new quality of education focused on intellectual and creative development, the formation of a competent person capable of innovation, which is determined not only by the amount of knowledge gained, but also the ability to use them, independent activity, learning and self-improvement throughout life. This can be achieved by forming the personality of the student, who at work will ensure compliance with safety and health, guided by current regulations on labor protection, to confidence in their abilities, the ability to navigate in an extreme situation. A rationally organized system of education in the study of occupational safety disciplines should become the basis and one of the determining factors in shaping the personality of the modern production manager.

\section{Formulation of problem}

The relevance of writing the article is due to the evergrowing need to find new, scientifically sound, practically significant and methodologically appropriate ways of successful training $[1,2]$ during the study of the discipline "Occupational Safety". Together with modern teaching methods (explanatory-illustrative, sign-context, case method, etc.), game methods belong to effective innovative technologies [3] during training [4-8], which allow to form a flexible, conscious, successful personality, capable of non standard think, solve urgent issues and act correctly in production situations.

The business game simulates a real situation, which is extremely important for the practical sphere of activity. General goals of business games in higher educational institutions: to immerse students in the atmosphere of intellectual activity, as close as possible to professional practical work, to create a game atmosphere that changes dynamically, depending on right and wrong actions and decisions $[8,9]$. 
The discrepancy between the state of development of communication skills of future professionals, their ability to effectively solve problems in various areas of professional activity with mandatory consideration of labor protection requirements and guarantee the preservation of life, health and ability to work, as well as the role of business games in this process direction of our research. Note that the business game is aimed at developing the ability to analyze specific, specific practical situations and solve professional problems, encourages students to seek solutions to production problems.

\section{Analysis of recent research results}

The essence of active teaching methods is that the student acquires the necessary knowledge by studying and analyzing various sources of information related to the practical activities in which the training is conducted [8]. The peculiarities of the methods of active learning are the forced activation of the student's thinking, he is obliged to be active, regardless of whether he wants it or not and takes an active part in the learning process for a long time. The degree of motivation and emotionality, independent decision-making increases [4, 9]. Active teaching methods combine forms of individual and collective development of educational material that use the actual data of a particular problem and its theoretical generalizations. The most effective of them are situational methods: analysis of specific situations, solving practical problems, staging, analysis of incidents, business games [6]. The game method has a number of advantages in comparison with traditional methods of teaching in high school, because the purpose of the game is more consistent with the practical needs of students. This method allows you to connect a wide range of problems and the depth of their understanding, corresponds to the logic of activity, includes a moment of social interaction, prepare for professional communication [8]. The game is full of feedback and stronger in comparison with traditional methods, professional skills are formed, stereotypes are easier to overcome, and self-esteem is adjusted [9]. In the course of a business game the whole personality of a student is manifested, while traditional methods assume the dominance of only the intellectual sphere. It is possible to interpret, comprehend the results [10].

Business games have components that fundamentally distinguish them from other types of educational technologies, they have an algorithm of "correctness" and "incorrectness" of the decision, ie the student-participant of the game sees the impact of his decision on future events [ 11]. Although business games are primarily designed to prepare students for professional activities, immersing them in real practice, the game simulation model inevitably simplifies this task, mainly in the direction of providing experience in interpersonal and business relationships [12].

At the same time, business games, as a kind of simulation method, open for the university teacher the opportunity to study decision-making processes taking into account the individual characteristics of the student.

Business games have a lot to do with tests, performing detection and evaluation functions. However, if the tests involve answers to questions or mental solutions to the problem, the game is based on certain behaviors and actions, in addition, the game is usually the interaction of two or more subjects, ie collective, group interaction [3]. The game differs in complexity and interdependence of the solved problems, and if tests have fragmentary character, the game on the design covers a complex of interconnected actions in which the previous decisions, in many respects determine the following [13]. The game involves the simulation of a real situation, which is characterized by dynamism and variability, which allows you to identify such behavioral traits of the student, which can not be detected by conventional tests. The game is multifunctional: along with the function of assessing the qualities and knowledge of students, it can perform the functions of teaching, training and education of its participants, as well as solving research problems [14]. Evaluation of the effectiveness of a business game directly depends primarily on the process of its course, while the test is evaluated by the results of its implementation.

Business game brings the desired result when it is based on theoretical knowledge, the idea of the field of knowledge that it simulates, and is a logical continuation of the educational process, the transition to a practical behavioral stage [15]. Students receive and learn more information based on specific examples, which contributes to the acquisition during the game of skills of constructive decision-making, increases the motivation of students to learn innovative knowledge. Students' self-esteem increases, and for those who had overestimated self-esteem before the game, it becomes more objective [12]. The experience gained in the process of business game makes it possible to more accurately assess the probable real situations [16].

The use of business games in such disciplines as civil protection, life safety or occupational safety will promote the practical use and acquisition of theoretical knowledge that can be used in the further activities of the student as a specialist [5].

\section{Purpose of research}

The purpose of the research is to develop, scientifically substantiate and experimentally test the methodology of the business game "Providing first aid to victims in case of an accident at production", aimed at working out a sequence of actions to provide first aid in order of urgency and ability to maintain basic life functions. before the arrival of the emergency medical team.

\section{Research results}

As noted above, a business game is a way to enhance the educational and cognitive activities of students, which encourages them to intensive mental and practical activities in the process of mastering the material, when active not only the teacher but also students. The basis of the traditional explanatory-illustrative approach to learning is the principle of transferring knowledge to students in a ready form. In the case of the use of active methods there is a shift of emphasis in the direction of activating the mental activity of students [18]. Methods of active learning 
can be used at different stages of the learning process: the first stage - the initial acquisition of knowledge. These can be a problem lecture, heuristic conversation, educational discussion, etc. The second stage - control of knowledge (fixing), such methods as collective mental activity, testing, etc. can be used. The third stage - the formation of professional skills, knowledge-based skills and the development of creative abilities, the possible use of simulated learning, game methods [16].

Consider the step-by-step algorithm of the business game "Providing first aid to victims in case of an accident at production", which was conducted with students of higher education after studying the topic. Technical equipment: cards with tasks, bandages, splints, bandaging material, first aid kit, mannequin-simulator for practicing techniques of cardiopulmonary resuscitation.

Stages and sequence of the business game:

Stage I. Introduction to the game. Participants get acquainted with the content, goals and objectives of the game, the general rules. The teacher provides counseling and instruction.

Stage II. Separation of roles among students. The optimal group size is 3 - 4 people. Each group receives a specific problem situation, distributes roles among group members who interact with each other through discussion, exchange of experience

Stage III. Immersion in the game. Students get acquainted in detail with the proposed situation.

Stage IV. Study and systematic analysis of problems. The participants of the game analyze the situation, the "highlight" is that no one but the student who portrays the "intellectual victim" knows what happened to the victim. They should determine this only by indirect signs - a brief description of the victim's condition by the teacher, the explanations (often specifically confusing) given by the "victim", as well as the actions taken by the victim, such as screaming "in pain" when touching a broken legs, or "suffocating", etc.

Stage V. Gameplay. There is a search or development of solutions, forecasting potential problems, risks and other consequences of the problems and specific actions. During the discussion, a collective decision is made, a clear algorithm for providing first aid to the victim is developed. The main points of the lesson are recorded in the notebooks.

Stage VI. General discussion. Players present and justify their decisions. The result of the work is evaluated by participants of other groups. The teacher can also speak about the results of the discussion, but only with commentators on the content of the discussion, and not on the whole game.

Stage VII. Summing up the game. The need for this stage is especially important, at this time the decisions of teams and algorithms for providing first aid to the victim are evaluated, there is an acquaintance with different approaches to care, their effectiveness and competitiveness are determined. At this stage, points, penalties and incentives are calculated, the best players are identified, the game is logically completed.

Stage VIII. "Unloading" from the game. The final part of the game is devoted to the participants' thoughts on the prospects of using such learning technologies in the educational process.
In a business game, action is always characterized by problem analysis, weighing alternatives, developing strategies and making decisions [19]. Accordingly, in a model that simulates the solution of a problem, it is necessary to make simplifications to some important decision-making processes and, thus, to important data, structures and processes. Conflicts that require decisionmaking within one group or between conflicting parties or decisions that go beyond the conflict are best suited for this. The selection of game groups is very important and therefore it needs to be considered especially carefully. The role of moderator of the game is not performed by the teacher, but in our example, the head and leader of the group, and to some extent competent listeners. The game leader gives the participants freedom of action, he allows them to follow the learning path and make mistakes. Tasks of the game manager: 1) to conduct separate phases of game and to provide with necessary materials. It cannot influence the group's decisions, but it can bring in new additional information, materials and suggestions; 2) represents groups that are not engaged in the game, monitors compliance with time and proximity to reality; 3 ) he is a mediator in case of violation of the rules of the game and in the event of conflicts. The business game requires certain conditions in terms of premises and time, it also requires technical equipment, which is often difficult to create in the daily learning process.

Our research was conducted among students of the Faculty of Veterinary Medicine of NULES of Ukraine (Kyiv). Three control groups were selected, in which the topic "Providing first aid to victims in case of an accident at production" was presented in lecture form, and three research groups, where practical classes were conducted in the form of a business game. The degree of assimilation of educational material by students on a 100-point system in research and control groups was analyzed.

Checking the effectiveness of the implementation of a new method of training, the assimilation of the material took place through the preparation of reports on the work performed, demonstration of algorithms for providing first aid to the victim

After conducting practical classes in the form of a business game, the degree of assimilation of educational material by students was analyzed in comparison with students of control groups, in which this topic was presented in lecture form. The form of student certification consisted of answers to test tasks and descriptive questions of the training module. We compared the average scores of responses on a 100-point system with the results of evaluations in the control groups, taking into account the overall score of the groups for the school year (tab. 1).

The obtained data showed that the level of knowledge of students in groups, where practical classes were conducted in the form of a business game, was much higher compared to students of control groups. (fig. 1). Statistical analysis of the results of the research was performed using the Microsoft Excel 2003 computer program. The average score of the responses in the control groups was 72.25 points, and in the experimental groups - 80.45. The standard deviation from the mean is \pm 0.954 and \pm 0.12 , respectively.

We identified Student's unrelated (odd) criterion to compare groups formed from different people, it was 
6,445 . The reliability of the measurements had the highest level of significance $(\mathrm{p}<0.001)$.

Table 1. Results of the conducted assessment of students' knowledge on the topic "Providing of first aid to victims in accidents at production" and the average score of groups for the academic year, in the control and research groups.

\begin{tabular}{|c|c|c|c|c|c|}
\hline \multicolumn{3}{|c|}{ Control groups } & \multicolumn{3}{|c|}{ Study groups } \\
\hline group & group & group & group & group & group \\
\hline 1 & 2 & 3 & 4 & 5 & 6 \\
\hline 91 & 98 & 95 & 98 & 91 & 91 \\
\hline 94 & 90 & 90 & 98 & 84 & 95 \\
\hline 90 & 95 & 82 & 95 & 98 & 95 \\
\hline 74 & 90 & 90 & 92 & 90 & 77 \\
\hline 86 & 92 & 90 & 85 & 80 & 90 \\
\hline 60 & 84 & 90 & 80 & 92 & 87 \\
\hline 71 & 82 & 76 & 88 & 90 & 90 \\
\hline 69 & 84 & 76 & 89 & 74 & 84 \\
\hline 60 & 82 & 75 & 78 & 90 & 88 \\
\hline 60 & 74 & 60 & & 93 & 85 \\
\hline 69 & 74 & 76 & & 78 & 81 \\
\hline 60 & 82 & 60 & & 80 & 77 \\
\hline \multirow[t]{4}{*}{60} & 62 & 74 & & & 85 \\
\hline & 60 & 90 & & & 80 \\
\hline & 60 & & & & \\
\hline & 60 & & & & \\
\hline \multicolumn{6}{|c|}{ The average values of the control module } \\
\hline 72,61 & 74,82 & 75,33 & 80,4 & 80,3 & 80,66 \\
\hline \multicolumn{6}{|c|}{ Average performance values } \\
\hline 58,92 & 69,46 & 71,35 & 75,17 & 71,1 & 69,38 \\
\hline
\end{tabular}

Comparing the data of average scores of responses from the control module of students on a 100-point system with the overall score of groups for the academic year, a direct correlation was established between the two data sets.

The strength of the correlation bond was 0.707877 , ie it is in the range from \pm 0.7 to \pm 0.99 , according to the scale - this is a strong dependence, as evidenced by the level of significance. The overall success of students from all disciplines during the year in the control and research groups was lower than the results of the control module on "Providing first aid to victims in case of an accident at production". This may be due to students' personal interest in learning about this topic. Almost everyone has faced situations where someone needs urgent help, some have seen help already provided, and sometimes we need it ourselves. Everyone should know the basics of first aid, because it is before the arrival of doctors often comes a precious time when you can save lives or prevent deterioration.

The activity in the form of a business game turned out to be extremely interesting and useful for all students, as they had the opportunity not only to hear the rules of first aid for victims in case of an accident, but also to feel like real rescuers. The game provided an opportunity to test the acquired knowledge and skills. On special mannequins, future specialists learned to do cardiopulmonary resuscitation, stop bleeding and provide first aid for burns and frostbite. Game participants learned how to use improvised means, items of clothing, and other items to provide first aid. Most importantly, students realized that it was important to pinpoint symptoms and, without wasting time, make decisions about actions.

Students asked questions and actively participated in training sessions.

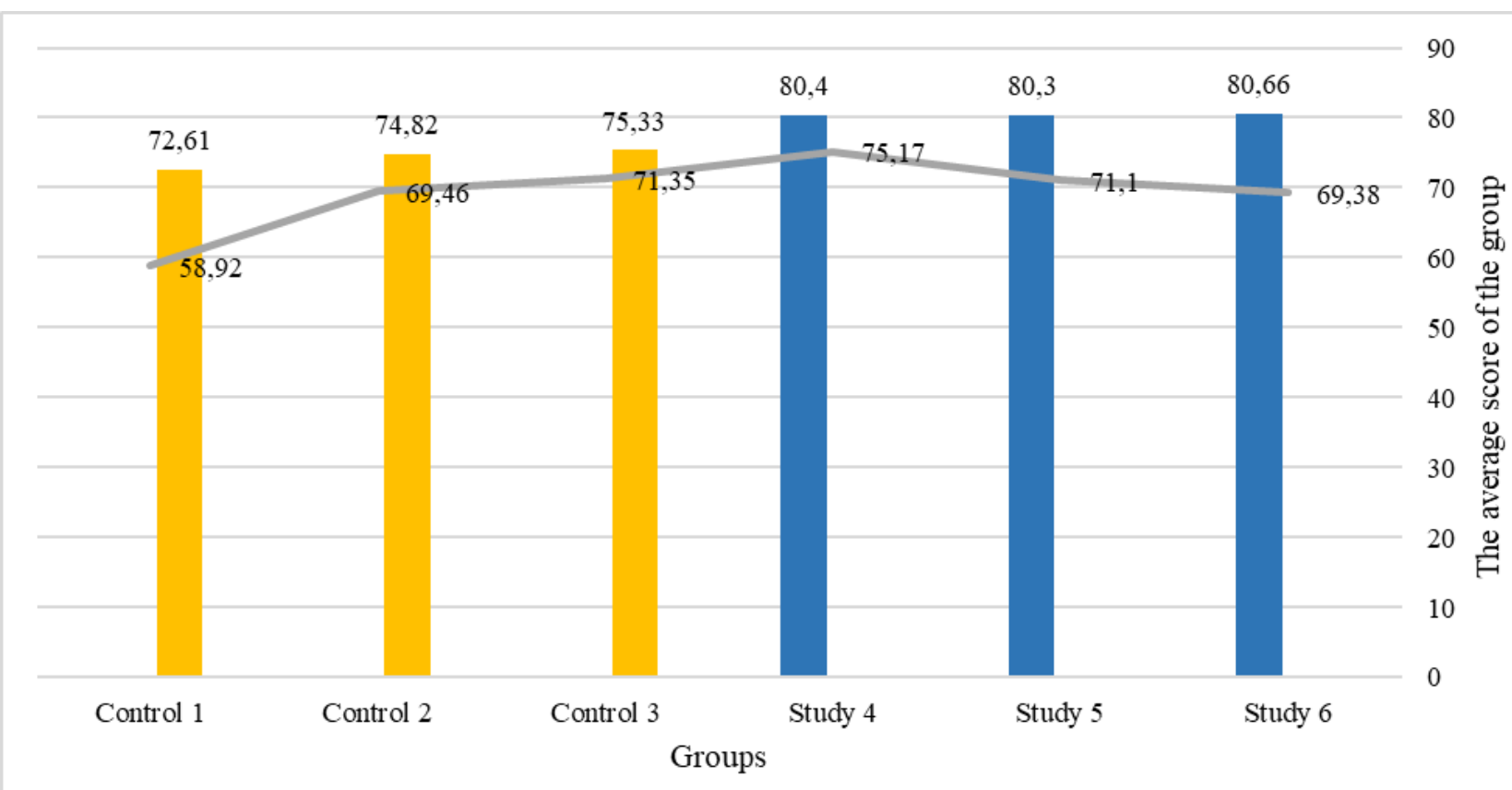

Business game Traditional methods $\quad$ Overall performance score

Fig. 1. Comparison of average scores of answers from the training module on a 100-point system for different methods of teaching the discipline and the overall score of groups for the academic year. 
All participants of the game noted that such classes provide an opportunity to receive very useful information and acquire the necessary skills, because now they can use their knowledge in difficult and extreme situations in the workplace, as well as in everyday life. People often die because others are unable to help them in time due to lack of basic medical knowledge. So you need to know how to keep yourself and other people healthy.

Assessment of students involved in the business game also had some benefits for the teacher. Often, in written or oral tests, we are faced with the problem of learning, in which the student does not understand the essence of the material, has difficulty using it in practice in the future. Conducting a business game makes it possible to assess the readiness of students more objectively, to identify all the "weaknesses" or gaps in the knowledge of students, which can later serve to organize a more detailed analysis of a material.

It was found that the use of the developed business game in the educational process allowed to increase the level of assimilation of material for providing first aid to victims in case of an accident by $7.7 \%$.

The above method of preparing and conducting a business game "Providing first aid to victims in case of an accident at production" can be used as one of the active teaching methods that allow students to act independently for some time in a simulated situation, to obtain the necessary skills and rules for providing first aid to victims in case of an accident. The analysis of different ways of solving the situation, actions, methods and ways out of the simulated situation contributes to a significant improvement in the quality of the educational process and the accumulation of experience. Business games in the educational process allow future professionals to form not only certain professional skills, but also certain moral traits of the individual in terms of professional duties: initiative, principledness, diligence, honesty $[12,20]$.

\section{Conclusions}

1. Assessment of the assimilation of the material allows to state, although not significant, $7.7 \%$, but a probable increase in the efficiency of the assimilation of the material when applying the methodology of the business game " Providing first aid to victims in case of an accident at production." The peculiarity of the use of business games in teaching students is that this approach allows to elaborate both theoretical knowledge and practical skills of providing first aid to victims in case of an accident.

2. In addition, conducting practical classes in the form of a business game is more interesting for students, because it involves not only identifying the level of theoretical training, but also the use of knowledge in a simulated situation close to reality, allows students to avoid certain fears that sometimes arise work in an emergency. And also, in particular due to the emotional component, leads to a much deeper assimilation of the material.

3. Conducting a business game provides an opportunity to more objectively assess the readiness of students, to identify any "weaknesses" or gaps in the knowledge of students, which can further serve to organize a more detailed analysis of a material.

4. The above method of preparing and conducting a business game can be used as one of the active teaching methods, which is an effective pedagogical tool aimed at forming thinking and can be recommended as an alternative form of classroom work.

\section{References}

1. Polishchuk O., Tomchuk M., Varchuk R. (2018). Use of business games for increasing the efficiency of the discipline study «Civil protection and labor protection is in industry» Pedahohika bezpeky. № 1, 43-50.

2. Yatsukh O. V. (2018). Legislative new production on the issues and problems that they do during the professional work of masters in civil security. Vseukrayins'kyy naukovo-praktychnyy zhurnal "Dyrektor shkoly, litseyu, himnaziyi" ". №6. B. 2. Tom III (81). 382-392.

3. Pelekh Yu. V., Nepelyak M. S. (2017). The global reach space of moderninstitution of higher education: innovative sight. Onovlennya zminy, formy ta metody navchannya ta zdobuttya navchal'noho kursu. 17, 22-25.

4. Yehudina Ye.D., Khanyukov O.O., Holovach I. Yu., Kalashnykova O.S., Sapozhnychenko L. V. (2018). Business game as a method of an active education for the 6th year students in the «Internal medicine» discipline study. Visnyk problem biolohiyi ta medytsyny. Vol. 4. Tom 2 (147). 217-222.

5. Shvets L. S. (2016). Organization of business simulation in practical classes in medical biology. Medychna osvita. № 1.112-114.

6. Oliynyk N. A. (2018). Methods of training future agricultural engineers. Pedahohika stvoryuye osobystist' u vyshchiy ta zahalnoosvitniy shkoli: zb. nauk. pr. Zaporizhzhya: KPU, Vol. 60. T. 2. 134-138.

7. Vasylenko O. V. (2015). Experience in using modern teaching methods in the training of successful professionals in educational institutions. Naukovi zapysky. Seriya: Problemni metodyky fizyko-matematychnoyi ta tekhnolohichnoyi osvity. Vol. 7 (I), 118-121.

8. Dereza O. O., Dereza S. V. (2017). Business game and its possibilities in professional training of future engineers. Zbirnyk naukovo-metodychnykh robit: Udoskonalennya rezul'tatyvno-vypusknoho protsesu u vyshchomu navchal'nomu zakladi. Vol. 20. Melitopol 100105 .

9. Pertseva T.O., Myronenko O. V., Dmytrychenko V. V., Harahulya H. A., Botvinikova L. A. (2016). Features of pedagogical technology "Business Game" in the learning process of students in higher education Proceedings of the XIII All-Ukrainian scientific-practical conference: "Current issues of medical education" May 12-13, Ternopil. T. 2, 157-158.

10. Haydenko Y. O. (2016). Methodical recommendations for the organization and observance of business games in foreign language classes in technical universities [Electronic resource]. Kyiv. NTUU "KPI". 86.

11. Shvets A. D. (2016). Game technologies in the educational Ukrainian language as a foreign language. Naukovyy visnyk Pivdennoukrayinskoho natsionalnoho 
pedahohichnoho ta universytetu imeni K.D. Ushynskoho. № 5 (112), 106-112.

12. Surhova S. Y. (2018). The use of business games in the formation of the creative personality of future social workers. Pedagogy of creativity of representatives in higher and general education school: zb. nauk. pr. Zaporizhzhya: KPU, Vol. 60. T. 2. 168-172.

13. Zakharenko V. O., Yurchenko M. A. (2018). Quality of education. problems and ways of resolving issues of training specialists. Modernizatsiya vyshchoyi osvity ta problemy upravlinnya yakistyu pratsyuyuchykh. Orhanizatsiyna systema vplyvaye "vyshcha osvita - rynok pratsi". Kharkiv. KHDUKHT, 155-156.

14. Morozova T. S., Makarov Yu. A. (2017). Business game as a modern method of active education. Nauchnyy almanakh. № 4-2 (30). 95-99.

15. Denysenko L. N., Derevyanchenko S. P., Matveev S. V. (2016). Application of problem teaching method in conjunction with a business game for the training of students of the Faculty of Dentisty. International Journal Of Experimental Education, № 4. (CH. 2), 232234.

16. Klymenko I. S. (2019). Business games, imitation actions, cases: manual. Moscow. "KDU", "Dobrosvet", 128.

17. Lysykhina N. V. (2017). Business game as the ability to increase the efficiency of the educational process in the study of the discipline "First Aid". Innovative methods and educational technologies training of law enforcement officers: materialy Vseros. nauch.- prakt. konf. Rostov-na-Donu. 35-37.

18. Mezentseva O.I. (2018). Modern pedagogical technologies: a textbook for bachelor students studying in pedagogical directions and specialties. author-compiler: O.I. Mezentseva; pod. red. Ye.V. Kuznetsovoy. Novosibirsk: OOO "Nemo Press", 140.

19. Lisikhina N. V. (2018). An innovative approach to teaching lawyers the basics of first aid in emergency situations. Pedagogicheskiye nauki. №15. 401-402.

20. Litvinov A. S. (2017). Pedagogical provision of innovation in education: textbook. Instruction. za zah. nauk. red. d. ped. n., prof. V. V. Borysova. Sumy. Universytetska knyha. 265.

\section{Список літератури}

1. Поліщук О., Томчук М., Варчук Р. Використання ділових ігор для підвищення ефективності вивчення дисципліни «Цивільний захист та Охорона праці в галузі». Педагогіка безпеки. 2018. № 1. С. 43 50.

2. Яиух О. В. Застосування новітніх засобів навчання та проблеми їх впровадження під час про-фесійної підготовки магістрів 3 цивільної безпеки. Ди-ректор школи, ліцею, гімназії. 2018. №6. Кн. 2. Том III (81). C. 382-392.

3. Пелех Ю. В., Непеляк М. С. Глобалізаційний вимір сучасного вищого навчального закладу: інно-ваційний погляд. Оновлення змісту, форм та методів навчання і виховання в закладах освіти. 2017. Вип. 17. C. $22-25$.
4. Єгудіна Є.Д., Ханюков О. О., Головач І. Ю., Калашникова О. С., Сапожниченко Л. В. Ділова гра, як метод активного навчання для студентів 6 курсу при вивченні дисципліни «Внутрішня медицина». Вісник проблем біології і медицини. 2018. Вип. 4. Том 2 (147). C. 217-222.

5. Швець Л. С. Організація ділової гри на практичних заняттях 3 медичної біології. Медична освіта. 2016. № 1. C. 112-114.

6. Олійник Н. А. Методика навчання майбутніх агроінженерів. Педагогіка формування творчої осо-бистості у вищій і загальноосвітній школах : зб. наук. пр. Запоріжжя : КПУ, 2018. Вип. 60., Т. 2. С. 134-138.

7. Василенко О. В. Досвід застосування сучасних методів навчання при підготовці фахівців рес-торанної справи у вищих навчальних закладах. Нау-кові записки. Серія: Проблеми методики фізико-математичної і технологічної освіти. 2015. Вип. 7 (I). С. 118-121.

8. Дереза О. О., Дереза С. В. Ділова гра та іiі можливості в професійній підготовці майбутніх інженерів. Збірник науково-методичних праць: Удосконалення освітньо-виховного процесу в вищому навчальному закладі. Вип. 20. Мелітополь. 2017. С. 100-105.

9. Периева Т. О., Мироненко О. В., Дмитричепко В. В., Гарагуля Г. А., Ботвінікова Л. А. Особливості застосування педагогічної технології «ділова гра» у навчальному процесі студентів вищих медичних навчальних закладів. Матеріали XIII Всеукраїнської наук.-практ. конф.: «Актуальні питання якості медичної освіти» (12-13 трав. 2016 р.). Тернопіль. 2016. Т. 2. C. 157-158.

10. Методичні рекомендації до організації та проведення ділових ігор на заняттях з іноземної мови у технічних університетах [Електронний ресурс]: Уклад.: Ю. О. Гайденко. К.: НТУУ «КПІ», 2016. 86 с.

11. Швещь Г. Д. Ігрові технології в навчанні української мови як іноземної. Науковий вісник Південноукраїнського національного педагогічного університету ім. К.Д. Ушинського. 2016. №5 (112). С. 106-112.

12. Сургова С. Ю. Використання ділової гри в процесі формування творчої особистості майбутніх соціальних працівників. Педагогіка формування творчої особистості у вищій і загальноосвітній школах: зб. наук. пр. Запоріжжя: КПУ, 2018. Вип. 60. Т. 2. С. 168172.

13. Захаренко В. О., Юрченко М. А. Якість осві-ти, проблеми та напрями вирішення питань підгото-вки фахівців. Модернізація вищої освіти та проблеми управління якістю підготовки фахівців. Організація системи взаємодії «вища освіта - ринок праці». Харків. ХДУХТ. 2018. С. 155-156.

14. Морозова Т. С., Макаров Ю. А. Деловая игра как современный метод активного обучения. Научный альманах. № 4-2 (30). 2017. С. 95-99.

15. Денисенко Л. Н., Деревянченко С. П., Матвеев С.В. Применение проблемного метода обучения совместно с деловой игрой для обучения студентов стоматологического факультета. Международный журнал экспериментального образования. 2016. № 4 (Ч. 2). С. 232-234.

16. Клименко И. С. Деловые игры, имита-ционные упражнения, кейсы. Москва. «КДУ», «Добросвет», 2019. 128 c. 
17. Лисихина Н. В. Деловая игра как способ повышения эффективности учебного процесса при изучении дисциплины «Первая помощь». Инно-вационные методы и образовательные технологии подготовки сотрудников органов внутренних дел: материалы Всерос. науч.- практ. конф. Ростов-на-Дону. 2017. C. 35-37.

18. Современные педагогические технологии: учебное пособие для студентов-бакалавров, обу-чающихся по педагогическим направлениям и спе-циальностям. автор-составитель: О. И. Мезенцева; под. ред. Е. В. Кузнецовой. Новосибирск: ООО «Немо Пресс», 2018. $140 \mathrm{c}$.

19. Лисихина Н. В. Инновационный подход при обучении юристов основам первой помощи при чрезвычайных ситуациях. Педагогические науки. 2018. №15. С. 401-402.

20. Литвинов А. Сю Педагогічний провайдинг інновацій в освіті. Суми. Університетська книга, 2017. $265 \mathrm{c}$.

\section{ДІЛОВА ГРА ЯК СПОСІБ ПІДВИШЕННЯ ЕФЕКТИВНОСТІ НАВЧАЛЬНОГО ПРОЦЕСУ ПРИ ВИ-ВЧЕННІ ТЕМИ НАДАННЯ ДОМЕДИЧНОЇ ДОПОМОГИ ПОТЕРПІЛИМ У РАЗІ НЕЩАСНИХ ВИПАДКІВ \\ С. М. Голопура, П. О. Чмара}

Анотація. Статтю присвячено теоретичному та практичному аналізу використання методу ділової гри для професійної підготовки майбутніх спеціалістів, які за своїми службовими обов'язками повинні володіти основними практичними навичками з рятування та збереження життя людини у разі нещасного випадку на виробництві, та відповідно до закона зобов'язані здійснювати невідкладні дії та організаційні заходи. Зазначено, що проблему застосування гри в системі соціально-педагогічної роботи широко представлено 3 погляду педагогіки в загальних дослідженнях. Разом із тим спостерігаємо дефіцит вітчизняних досліджень, присвячених розробленню теоретичних основ і вдосконаленню практики використання ділової гри як активного працеохоронного методу навчання майбутніх спеціалістів. Визначено специфіку ігрової діяльності, яка полягає в напрямі профілактичної, превентивної спрямованості гри як методу організації змістовного навчання майбутніх фахівців.

Мета досліджень - розробити, науково обгрунтувати та експериментально перевірити методику ділової гри «Надання домедичної допомоги потерпілим у разі нещасного випадку на виробництві», спрямовану на відпрацювання студентами послідовності дій щодо надання домедичної допомоги в порядку терміновості та вміння підтримувати основні життєвих функції потерпілого до приїзду бригади екстреної медичної допомоги. Результатом таких ігор може бути як безпосередній розвиток якостей особистості, так і демонстрація практичної підготовки майбутніх фахівців. Програвання певних ситуацій, залучення учасників гри до ситуації вибору є реальним шляхом до впевненості у своїх силах, вмінню правильно орієнтуватись в екстремальній ситуації та використовувати підручні засоби для надання допомоги потерпілим.
У даній роботі проаналізовано ступінь засвоєння навчального матеріалу студентами після проведення практичних занять у формі ділової гри порівняно зі студентами контрольних груп, в яких цю тему подавали у лекційному вигляді. Форма атестації студентів полягала у відповідях на тестові завдання та описові запитання навчального модуля. Порівнювали усереднені оцінки відповідей за 100-бальною системою з результатами оцінювання у контрольних групах 3 врахуванням загального балу успішності студентів за навчальний рік.

Ключові слова: ділова гра, охорона праці, надання домедичної допомоги потерпілим, екстримальна ситуація, ступінь засвоєння навчального матеріалу.

\section{ДЕЛОВАЯ ИГРА КАК СПОСОБ ПОВЫШЕНИЕ ЭФФЕКТИВНОСТИ УЧЕБНОГО ПРОЦЕССА ПРИ ИЗУЧЕНИИ ТЕМЫ ПРЕДОСТАВЛЕНИЯ ДОМЕДИЦИНСКОЙ ПОМОЩИ ПОСТРАДАВШИМ ПРИ НЕСЧАСТНЫХ СЛУЧАЯХ С. Н. Голопура, П. А. Чмара}

Аннотация. Статья посвящена теоретическому и практическому анализу использования метода деловой игры для профессиональной подготовки будущих специалистов, которые по долгу службы должны владеть основными навыками по спасению и сохранению жизни человека в случае несчастного случая на производстве, и в соответствии с законом обязаны осуществлять неотложные действия и организационные мероприятия. Отмечено, что проблема применения игры в системе социальнопедагогичнои работы широко представлены с точки зрения педагогики в общих исследованиях. Вместе с тем наблюдаем дефицит отечественных исследований, посвященных разработке теоретических основ и совершенствованию практики использования деловой игры как активного трудоохранной метода обучения будущих специалистов. Определена специфика игровой деятельности, которая заключается в направлении профилактической, превентивной направленности игры как метода организации содержательного обучения будущих специалистов.

Цель исследований - разработать, научно обосновать и экспериментально проверить методику деловой игры «Предоставление домедицинской помощи пострадавшим при несчастном случае на производстве», направленную на отработку студентами последовательности действий по предоставлению домедицинской помощи в порядке срочности и умение поддерживать основные жизненные функции пострадавшего до приезда бригады экстренной медицинской помощи. Результатом таких игр может быть, как непосредственное развитие качеств личности, так и демонстрация практической подготовки будущих специалистов. Проигрывания определенных ситуаций, привлечения участников игры к ситуации выбора является реальным путем к уверенности в своих силах, умению правильно ориентироваться в экстремальной ситуации и использовать подручные средства для оказания помощи пострадавшим. 
В данной работе проанализирована степень усвоения учебного материала студентами после проведения практических занятий в форме деловой игры по сравнению со студентами контрольных групп, в которых эту тему подавали в лекционном виде. Форма атестации студентов заключалась в ответах на тэстовые задания и описательные вопросы учебного модуля. Сравнивали усредненные оценки ответов по 100балльной системе с результатами оценивания в контрольных группах с учетом общего балла успеваемости студентов за учебный год.

Ключевые слова: деловая игра, охрана труда, предоставление домедицинской помощи пострадавшим, экстримальная ситуация, степень усвоения учебного материала.

С. М. Голопура ORCID 0000-0001-9531-5344. П. О. Чмара ORCID 0000-0002-8793-5188. 